\section{Meiotic Behavior in a Tetraploid Rose and its Hybrid Progeny}

\author{
Yan Ma ${ }^{1}$, Charles F. Crane ${ }^{2}$, and David H. Byrne ${ }^{3}$ \\ Texas A\&M University, College Station, TX 77843-2133
}

Additional index words. Rosa, polyploidy, meiotic analysis, genomic affinity, breeding, tetrasomic, alloploid

\begin{abstract}
The tetraploid $(2 \mathrm{n}=4 \mathrm{x}=28)$ rose 86-7 (Rosa wichuraiana $\mathrm{x}$ R. rugosa rubra) and its hybrids with the thornless tetraploid rose cultivar Basye's Blueberry $(2 n=28)$ were analyzed for meiotic configuration frequencies and meiotic abnormalities. Genomic relationships in these hybrids were interpreted with the aid of a model of meiotic chromosome association in tetraploids. The closest-fitting model solutions indicated a 2:2 (AABB) pattern of genomic relationships, with $65 \%$ to $90 \%$ of all association between most closely related genomes. Some of the optimal solutions were transitional to a "ring4" pattern, in which one of the possible pairing arrangements is suppressed. The same configuration frequencies could also reflect a "4:0" pattern of equally similar genomes with fractionally more than two independent pairing and chiasma-forming domains per chromosome. Observed meiotic abnormalities included chromosome stickiness and asynchronous chromosome contraction within cells. Pollen stainability varied independently of meiotic irregularity or multivalent frequency. The observed configuration frequencies are consistent with partially tetrasomic inheritance that retains considerable heterozygosity, but allows individual contributions from parental genomes to become homozygous.
\end{abstract}

The large, diverse genus Rosa contains $\approx 200$ species in four subgenera and ten sections (Rehder, 1940), but only eight to ten of these species have been used in modern rose breeding (Krüssmann, 1981; Shepherd, 1954). Diseases are a significant problem with modern roses, and controlling them with fungicides is expensive. The principal diseases are blackspot [Diplocarpon rosae (Lib.) Wolf], powdery mildew \{Sphaerotheca pannosa [Wallr. (ex Fr.) Lev.]\}, rust (Phragmidium sp.), and rose mosaic [Prunus necrotic ringspot virus (PNRSV)]. Genetic resistance to these diseases occurs in some of the wild diploid $(2 \mathrm{n}=14)$ species of Rosa. Transferring resistance to the cultivated tetraploid $(2 n=28)$ gene pool requires a strategy to maximize fertility at each hybrid generation. One strategy is to double the chromosome number of a hybrid of resistant diploid species, and cross these tetraploids with the commercial tetraploid cultivars (Byrne et al., 1996; Ma et al., 1997).

Early cytogenetic studies in rose by Hurst (1929) and Erlanson (1933) focused on the subgenus Rosa. Subsequent papers (Klasterska 1971, 1978; Klasterska and Natarajan, 1974a, 1974b, 1975; Lata, 1982a, 1982b; Lata and Gupta, 1975) reported various meiotic behaviors in rose species and some

Received for publication 18 Oct. 1999. Accepted for publication 31 Jan. 2000. The cost of publishing this paper was defrayed in part by the payment of page charges. Under postal regulations, this paper therefore must be hereby marked advertisement solely to indicate this fact.

${ }^{1}$ Department of Horticultural Sciences. ${ }^{2}$ Department of Soil and Crop Sciences.

${ }^{3}$ To whom requests for reprints should be addressed. E-mail address: d-byrne@tamu.edu

HortScience, Vol. 35(6), October 2000
Species in their parentage include $R$. gallica
L., $R$. chinensis Jacquin, $R$. foetida persiana (Lemaire) Rehder, $R$. x odorata Sweet, $R$. phoenicia Boissier, and $R$. moschata Herrmann. Hybrids from the cross between 'Basye's Blueberry' and the tetraploid 86-7 were selected in 1990 for their health and high vigor.

Small floral buds were collected between 8:00 and 10:00 AM, sliced apically from the bottom to improve penetration of the fixative, and fixed in 2 acetone : 1 acetic acid (v:v) supplemented with $2 \%$ polyvinylpyrrolidone. After an initial $30 \mathrm{~min}$ at room temperature, the fixative was replaced with fresh fixative, and fixation continued for 1$3 \mathrm{~d}$ at $4{ }^{\circ} \mathrm{C}$. Any subsequent storage was in $70 \%$ ethanol at $4{ }^{\circ} \mathrm{C}$; many of the preparations were made with recently fixed anthers. The buds were transferred to water for a few hours before squashing. Meiotic configurations were examined from acetocarmine squashes made on a hot plate at $80^{\circ} \mathrm{C}$. Care was taken to remove anther-wall debris before squashing. The slides were sealed with dipilatory wax and stored at $-20{ }^{\circ} \mathrm{C}$ prior to examination under brightfield and phase contrast with a $100 \times$ objective. At diakinesis and metaphase I, univalents, bivalents (ring or rod), trivalents, and quadrivalents (ring or chain) were counted. The observed configuration frequencies were possibly biased toward bivalents and univalents because of the need to avoid the visibly abnormal cells with chromosome clumping, which may have been caused by a high frequency of multivalents. Since quantifying such observational errors is difficult, the configuration frequencies have been analyzed as if they were accurate.

Genomic interrelationships were inferred from the meiotic configuration frequencies with numerical models of chromosome pairing in diploids and tetraploids. The model for diploids estimates the probability that the average long or short chromosome arm produces at least one chiasma (Sybenga, 1975). The model for tetraploids (Crane, 1995; Crane and Sleper, 1989) not only estimates the probability that the average long or short arm produces at least one chiasma, but also the probability of each possible pairing between arms from different genomes. The model for diploids gives a single solution, consisting of a binding probability $a$ for long arms and a binding probability $b$ for short arms. The model for tetraploids typically gives a range of solutions that specify the same configuration frequencies. Because chromosomes compete for pairing partners in tetraploids, $a, b$, and six pairwise association probabilities could be estimated. These probabilities, denoted $s_{1}, s_{2}, s_{3}, s_{4}, s_{5}, s_{6}$, respectively, represent association between genomes 1 and 2, 1 and 3,1 and 4, 2 and 3,2 and 4, and 3 and 4, where numbers 1-4 designate the different genomes. Because the model embodies a geometric paradigm of genomic relationship, many of its solutions cannot be represented in the traditional alphabetic convention of $\mathrm{AABB}, \mathrm{AABC}, \mathrm{AAAB}$, or ABCD.

As previously stated, the model typically gives a range of solutions when expected 
configuration frequencies exactly match observed configuration frequencies. These solutions can be characterized by means of numerical indices that are based on eight distinct patterns of genomic relationship. The solution algorithm was designed to seek out extreme values of these indices, and thus of the underlying association probabilities, that maintained equally good fit to the observed configuration frequencies. In practice, the range of model solutions narrows greatly when fit is not perfect. Such was the case here, where the optimized model solutions generally differed only in the third significant digit. Therefore, only one solution is presented for most of the tetraploids, with exceptions only where the differences affected the first or second digit.

\section{Results and Discussion}

Both diploid parents of 86-7 ( $R$. wichuraiana and $R$. rugosa rubra) exhibited mostly bivalent pairing, although unexpectedly there were a few ( $4 \%$ to $6 \%$ ) univalents. Rod bivalents prevailed in both species and the model indicated a long : short arm ratio from 3:1 to 4:1 (Table 1). Meiotic configuration frequencies in the diploid hybrid, 86-7 $(2 \mathrm{n}=2 \mathrm{x}=14)$, resembled those in its parents, as there were no multivalents, a few univalents, predominantly rod bivalents and an optimized arm ratio of $3.4: 1$. These similarities indicate that the genomes of the sections Synstylae ( $R$. wichuraiana) and Cassiorhodon (R. rugosa rubra) are similar and capable of extensive genetic exchange. This is reflected in the frequent multivalent formation (average of 8.67 out of 28 chromosomes involved) of the tetraploid derivative of the diploid 86-7. However, the model (Table 2) indicates preferential pairing, rather than completely random pairing, among the homologs in this tetraploid. About $58 \%$ of the pairing was in a 2:2 pattern and $19 \%$ was in a 2:1:1 pattern. The models also found different effective arm ratios for the diploid and tetraploid forms of 86-7. The tetraploid appeared to have equal arms, whereas the diploid had a long : short arm ratio of 3.4:1 (Table 1). The difference in model results reflects differences in the observed proportions of ring and rod bivalents, and the effect of multivalent frequencies in the tetraploid. Possible causes of this difference include interpretive observational bias, asynchronous chiasma release at the transition to anaphase I, or a direct effect of ploidy on chiasma interference or the general regulation of chiasma distribution.
The complex hybrids 'Basye's Blueberry' and 74-193 (pollen parent of 'Basye's Blueberry') resembled one another in configuration frequencies and optimized model results. The closest-related genomes paired $\approx 85 \%$ of the time, the estimated long : short arm ratio was $1.7: 1$, and both had less than $20 \%$ of their chromosomes pairing as multivalents. Nevertheless, the models indicated significant homeologous exchange in each hybrid. Since these are complex hybrids, they probably contain recombinant chromosomes derived from more than one of their ancestral species, such that some of the multivalents would reflect a type of translocation heterozygosity involving homeologs. In this case, the model would underestimate pairing preferentiality.

The tetraploid form of 86-7 exhibited about the same proportion of bound arms as did 74-193 and 'Basye's Blueberry', however, it had more than twice as many univalents, more $(31 \%)$ of its chromosomes were paired in multivalents, and only $78 \%$ of its pairing was between closest-related genomes (Tables 1 and 2). This would indicate greater opportunities for tetrasomic inheritance in tetraploid 86-7.

Diakinesis and metaphase I in hybrids between 'Basye's Blueberry' and 86-7

Table 1. Meiotic analyses ${ }^{\mathrm{z}}$ of chromosome pairing in 10 tetraploid $(2 \mathrm{n}=4 \mathrm{x}=28)$ rose (Rosa sp.) hybrids ('Basye's Blueberry' $\left.\times 86-7\right)$ and their parents.

\begin{tabular}{|c|c|c|c|c|c|c|c|c|c|c|c|c|c|}
\hline \multirow[b]{2}{*}{ Genotype } & \multicolumn{3}{|c|}{$\mathrm{F}$} & \multirow[b]{2}{*}{$\mathrm{O} / \mathrm{E}$} & \multicolumn{6}{|c|}{ Mean pairing per $\mathrm{PMC}$} & \multirow[b]{2}{*}{$g \mathrm{II} / \mathrm{II}$} & \multirow[b]{2}{*}{ TCM } & \multirow[b]{2}{*}{$\mathrm{c}$} \\
\hline & $2 n$ & $(\%)$ & $\mathrm{N}$ & & I & $d \mathrm{II}$ & $g \mathrm{II}$ & III & $d \mathrm{IV}$ & $g \mathrm{IV}$ & & & \\
\hline $74-193$ & 28 & 68 & 28 & $\begin{array}{l}\text { obs } \\
\exp \end{array}$ & $\begin{array}{l}.21 \pm 0.35 \\
0.942\end{array}$ & $\begin{array}{c}5.79 \pm 0.40 \\
5.56\end{array}$ & $\begin{array}{c}5.36 \pm 0.400 \\
5.58\end{array}$ & $\begin{array}{c}07 \pm 0.05 \\
0.10\end{array}$ & $\begin{array}{c}0.25 \pm 0.11 \\
0.40\end{array}$ & $\begin{array}{c}0.82 \pm 0.13 \\
0.71\end{array}$ & $0.48 \pm 0.03$ & $4.50 \pm 0.62$ & $0.74 \pm 0.01$ \\
\hline Basye's & & & & & & & & & & & & & \\
\hline Blueberry & 28 & 52 & 50 & $\begin{array}{l}\text { obs } \\
\exp \end{array}$ & $\begin{array}{c}0.66 \pm 0.14 \\
0.38\end{array}$ & $\begin{array}{c}5.46 \pm 0.35 \\
5.20\end{array}$ & $\begin{array}{c}5.42 \pm 0.29 \\
5.68\end{array}$ & $\begin{array}{c}0.10 \pm 0.04 \\
0.05\end{array}$ & $\begin{array}{c}0.28 \pm 0.08 \\
0.55\end{array}$ & $\begin{array}{c}1.04 \pm 0.14 \\
0.88\end{array}$ & $0.50 \pm 0.03$ & $5.58 \pm 0.73$ & $0.77 \pm 0.01$ \\
\hline $86-7$ & 14 & & 49 & $\begin{array}{l}\text { obs } \\
\exp \end{array}$ & $\begin{array}{c}0.78 \pm 0.16 \\
0.78\end{array}$ & $\begin{array}{c}4.84 \pm 0.13 \\
4.84\end{array}$ & $\begin{array}{c}1.78 \pm 0.11 \\
1.78\end{array}$ & 0.0 & 0.0 & 0.0 & $0.27 \pm 0.02$ & 0.0 & $0.60 \pm 0.01$ \\
\hline $86-7$ & 28 & 73 & 51 & $\begin{array}{l}\text { obs } \\
\exp \end{array}$ & $\begin{array}{c}2.63 \pm 0.22 \\
2.01\end{array}$ & $\begin{array}{c}2.92 \pm 0.20 \\
2.65\end{array}$ & $\begin{array}{c}5.43 \pm 0.25 \\
5.68\end{array}$ & $\begin{array}{c}0.20 \pm 0.06 \\
0.37\end{array}$ & $\begin{array}{c}0.45 \pm 0.08 \\
0.89\end{array}$ & $\begin{array}{c}1.57 \pm 0.13 \\
1.16\end{array}$ & $0.65 \pm 0.02$ & $8.67 \pm 0.63$ & $0.78 \pm 0.01$ \\
\hline $\begin{array}{l}R . \\
\text { wichuraiana }\end{array}$ & 14 & 92 & 51 & $\begin{array}{l}\text { obs } \\
\exp \end{array}$ & $\begin{array}{c}0.78 \pm 0.17 \\
0.78\end{array}$ & $\begin{array}{c}4.71 \pm 0.18 \\
4.71\end{array}$ & $\begin{array}{c}1.90 \pm 0.16 \\
1.90\end{array}$ & 0.0 & 0.0 & 0.0 & $0.29 \pm 0.03$ & 0.0 & $0.61 \pm 0.01$ \\
\hline $\begin{array}{l}\text { R. rugosa } \\
\text { rubra }\end{array}$ & 14 & 94 & 38 & $\begin{array}{l}\text { obs } \\
\exp \end{array}$ & $\begin{array}{c}0.53 \pm 0.16 \\
0.52\end{array}$ & $\begin{array}{c}5.32 \pm 0.15 \\
5.32\end{array}$ & $\begin{array}{c}1.42 \pm 0.14 \\
1.42\end{array}$ & 0.0 & 0.0 & 0.0 & $0.21 \pm 0.02$ & 0.0 & $0.58 \pm 0.01$ \\
\hline $90-67$ & 28 & 67 & 20 & $\begin{array}{l}\text { obs } \\
\exp \end{array}$ & $\begin{array}{c}0.90 \pm 0.27 \\
0.22\end{array}$ & $\begin{array}{c}0.80 \pm 0.17 \\
0.93\end{array}$ & $\begin{array}{c}6.25 \pm 0.53 \\
6.15\end{array}$ & $\begin{array}{l}0.0 \\
0.07\end{array}$ & $\begin{array}{c}0.35 \pm 0.13 \\
0.83\end{array}$ & $\begin{array}{c}2.90 \pm 0.32 \\
2.52\end{array}$ & $0.89 \pm 0.03$ & 13.0 & 0.93 \\
\hline $90-68$ & 28 & 66 & 44 & $\begin{array}{l}\text { obs } \\
\exp \end{array}$ & $\begin{array}{c}0.89 \pm 0.17 \\
0.81\end{array}$ & $\begin{array}{c}3.05 \pm 0.23 \\
3.01\end{array}$ & $\begin{array}{c}8.45 \pm 0.29 \\
8.49\end{array}$ & $\begin{array}{c}0.25 \pm 0.07 \\
0.08\end{array}$ & $\begin{array}{c}0.14 \pm 0.05 \\
0.42\end{array}$ & $\begin{array}{c}0.70 \pm 0.11 \\
0.57\end{array}$ & $0.74 \pm 0.02$ & $4.11 \pm 0.52$ & $0.85 \pm 0.01$ \\
\hline $90-69$ & 28 & 78 & 45 & $\begin{array}{l}\text { obs } \\
\exp \end{array}$ & $\begin{array}{c}0.60 \pm 0.14 \\
0.52\end{array}$ & $\begin{array}{c}4.96 \pm 0.30 \\
4.85\end{array}$ & $\begin{array}{c}5.29 \pm 0.26 \\
5.41\end{array}$ & $\begin{array}{c}0.20 \pm 0.06 \\
0.09\end{array}$ & $\begin{array}{c}0.71 \pm 0.11 \\
0.66\end{array}$ & $\begin{array}{c}0.87 \pm 0.14 \\
1.01\end{array}$ & $0.52 \pm 0.03$ & $6.91 \pm 0.56$ & $0.77 \pm 0.01$ \\
\hline $90-70$ & 28 & 60 & 27 & $\begin{array}{l}\text { obs } \\
\exp \end{array}$ & $\begin{array}{c}0.96 \pm 0.20 \\
0.74\end{array}$ & $\begin{array}{c}3.48 \pm 0.43 \\
3.03\end{array}$ & $\begin{array}{c}5.30 \pm 0.43 \\
5.54\end{array}$ & $\begin{array}{c}0.44 \pm 0.11 \\
0.19\end{array}$ & $\begin{array}{c}0.22 \pm 0.10 \\
1.15\end{array}$ & $\begin{array}{c}1.81 \pm 0.22 \\
1.24\end{array}$ & $0.60 \pm 0.04$ & $9.48 \pm 1.10$ & $0.82 \pm 0.01$ \\
\hline $90-72$ & 28 & 68 & 22 & $\begin{array}{l}\text { obs } \\
\exp \end{array}$ & $\begin{array}{c}0.55 \pm 0.19 \\
0.05\end{array}$ & $\begin{array}{c}0.41 \pm 0.17 \\
0.41\end{array}$ & $\begin{array}{c}2.95 \pm 0.40 \\
4.28\end{array}$ & $\begin{array}{l}0.0 \\
0.03\end{array}$ & $\begin{array}{c}0.23 \pm 0.09 \\
0.69\end{array}$ & $\begin{array}{c}4.95 \pm 0.29 \\
3.93\end{array}$ & $0.88 \pm 0.04$ & $20.73 \pm 1.0$ & $0.96 \pm 0.01$ \\
\hline $90-74$ & 28 & 68 & 34 & $\begin{array}{l}\text { obs } \\
\exp \end{array}$ & $\begin{array}{c}0.59 \pm 0.17 \\
0.46\end{array}$ & $\begin{array}{c}3.88 \pm 0.47 \\
3.70\end{array}$ & $\begin{array}{c}6.56 \pm 0.39 \\
6.67\end{array}$ & $\begin{array}{c}0.18 \pm 0.07 \\
0.08\end{array}$ & $\begin{array}{c}0.41 \pm 0.10 \\
0.82\end{array}$ & $\begin{array}{c}1.09 \pm-.17 \\
0.82\end{array}$ & $0.63 \pm 0.04$ & $6.53 \pm 0.72$ & $0.82 \pm 0.02$ \\
\hline $90-76$ & 28 & 60 & 32 & $\begin{array}{l}\text { obs } \\
\text { exp }\end{array}$ & $\begin{array}{c}0.44 \pm 0.16 \\
0.147\end{array}$ & $\begin{array}{c}1.41 \pm 0.29 \\
1.11\end{array}$ & $\begin{array}{c}6.50 \pm 0.36 \\
6.48\end{array}$ & $\begin{array}{c}0.13 \pm 0.06 \\
0.05\end{array}$ & $\begin{array}{c}0.06 \pm 0.04 \\
0.72\end{array}$ & $\begin{array}{c}2.78 \pm 0.25 \\
2.41\end{array}$ & $0.82 \pm 0.02$ & $11.75 \pm 1.0$ & $0.93 \pm 0.01$ \\
\hline $90-77$ & 28 & 69 & 16 & $\begin{array}{l}\text { obs } \\
\exp \end{array}$ & $\begin{array}{c}0.50 \pm 0.34 \\
0.20\end{array}$ & $\begin{array}{c}0.67 \pm 0.33 \\
1.07\end{array}$ & $\begin{array}{c}8.50 \pm 0.67 \\
8.44\end{array}$ & $\begin{array}{c}0.17 \pm 0.17 \\
0.04\end{array}$ & $\begin{array}{c}0.50 \pm 0.22 \\
0.52\end{array}$ & $\begin{array}{c}1.67 \pm 0.33 \\
1.64\end{array}$ & $0.93 \pm 0.03$ & $9.17 \pm 1.64$ & $0.94 \pm 0.01$ \\
\hline $90-80$ & 28 & 36 & 38 & $\begin{array}{l}\text { obs } \\
\exp \end{array}$ & $\begin{array}{c}0.82 \pm 0.26 \\
0.18\end{array}$ & $\begin{array}{c}0.76 \pm 0.14 \\
0.88\end{array}$ & $\begin{array}{c}6.45 \pm 0.41 \\
6.35\end{array}$ & $\begin{array}{c}0.08 \pm 0.04 \\
0.06\end{array}$ & $\begin{array}{c}0.21 \pm 0.07 \\
0.75\end{array}$ & $\begin{array}{c}2.92 \pm 0.24 \\
2.55\end{array}$ & $0.89 \pm 0.02$ & $12.76 \pm 0.94$ & $0.93 \pm 0.01$ \\
\hline $90-81$ & 28 & 29 & 17 & $\begin{array}{l}\text { obs } \\
\text { exp }\end{array}$ & $\begin{array}{c}2.00 \pm 0.87 \\
0.64\end{array}$ & $\begin{array}{c}0.86 \pm 0.40 \\
1.36\end{array}$ & $\begin{array}{c}5.86 \pm 1.39 \\
5.72\end{array}$ & $\begin{array}{l}0.0 \\
0.20\end{array}$ & $\begin{array}{c}0.57 \pm 0.57 \\
1.23\end{array}$ & $\begin{array}{c}2.57 \pm 0.72 \\
1.92\end{array}$ & $0.87 \pm 0.07$ & $12.57 \pm 3.4$ & $0.88 \pm 0.04$ \\
\hline
\end{tabular}

${ }^{2} 2 n=$ chromosome number in the genotype; F $(\%)=$ percentage of pollen fertility; $\mathrm{N}=$ no. of cells analyzed; I, $d$ II, $g$ II, III, $d \mathrm{IV}, g \mathrm{IV}=$ mean number of univalents, rod bivalents, ring bivalents, trivalents, chain quadrivalents, and ring quadrivalents per cell respectively; $g$ II/II, proportion of ring bivalents to total bivalents; TCM $=$ total no. of chromosomes in multivalents; $c$, proportion of potentially bound arms that actually are bound. 
Table 2. Chromosome binding and association probabilities estimated from meiotic configuration frequencies of the roses 86-7 (diploid and tetraploid), 'Basye's Blueberry', their parents, and 10 of their hybrids.

\begin{tabular}{|c|c|c|c|c|c|c|c|c|c|c|}
\hline \multirow[b]{2}{*}{ Genotype } & \multirow[b]{2}{*}{ Index type ${ }^{z}$} & \multicolumn{2}{|c|}{ Binding frequencies $^{y}$} & \multicolumn{6}{|c|}{ Proportions of MI association $^{\mathrm{x}}$} & \multirow[b]{2}{*}{$\mathrm{SSD}^{w}$} \\
\hline & & $\mathrm{a}$ & $\mathrm{b}$ & $\mathrm{S}_{1}$ & $\mathrm{~S}_{2}$ & $\mathrm{~S}_{3}$ & $\mathrm{~S}_{4}$ & $\mathrm{~S}_{5}$ & $\mathrm{~S}_{6}$ & \\
\hline $86-7(2 n=2 x)$ & & 0.924 & 0.275 & & & & & & & 0.0 \\
\hline $86-7(2 n=4 x)$ & $2: 2$ & 0.779 & 0.779 & 0.487 & 0.056 & 0.055 & 0.055 & 0.055 & 0.292 & 1.495 \\
\hline $74-193$ & $2: 2$ & 0.925 & 0.552 & 0.438 & 0.062 & 0.0 & 0.0 & 0.062 & 0.438 & 0.568 \\
\hline Basye's Blueberry & $2: 2$ & 0.969 & 0.567 & 0.422 & 0.078 & 0.0 & 0.0 & 0.077 & 0.423 & 0.816 \\
\hline R. rugosa rubra & & 0.952 & 0.213 & & & & & & & 0.0 \\
\hline R. wichuraiana & & 0.921 & 0.295 & & & & & & & 0.0 \\
\hline \multirow[t]{2}{*}{$90-67$} & $2: 2$ & 0.927 & 0.927 & 0.364 & 0.081 & 0.081 & 0.081 & 0.081 & 0.311 & 0.867 \\
\hline & ring4 & 0.927 & 0.927 & 0.364 & 0.085 & 0.077 & 0.077 & 0.085 & 0.311 & 0.867 \\
\hline $90-68$ & $2: 2$ & 0.846 & 0.846 & 0.498 & 0.044 & 0.0 & 0.0 & 0.044 & 0.414 & 0.139 \\
\hline \multirow[t]{2}{*}{$90-69$} & $2: 1: 1$ & 0.956 & 0.582 & 0.414 & 0.094 & 0.0 & 0.0 & 0.094 & 0.398 & 0.177 \\
\hline & $2: 2$ & 0.956 & 0.582 & 0.412 & 0.044 & 0.044 & 0.044 & 0.044 & 0.412 & 0.178 \\
\hline $90-70$ & $2: 2$ & 0.898 & 0.737 & 0.362 & 0.139 & 0.0 & 0.0 & 0.138 & 0.361 & 1.589 \\
\hline $90-72$ & $4: 0$ & 0.958 & 0.958 & 0.167 & 0.167 & 0.167 & 0.167 & 0.167 & 0.167 & 3.278 \\
\hline $90-74$ & $2: 2$ & 0.946 & 0.692 & 0.418 & 0.081 & 0.0 & 0.0 & 0.081 & 0.419 & 0.310 \\
\hline $90-76$ & $2: 2$ & 0.927 & 0.927 & 0.318 & 0.181 & 0.0 & 0.0 & 0.181 & 0.319 & 0.782 \\
\hline $90-77$ & $2: 2$ & 0.934 & 0.935 & 0.431 & 0.103 & 0.0 & 0.001 & 0.090 & 0.375 & 0.280 \\
\hline $90-80$ & $2: 2$ & 0.933 & 0.933 & 0.367 & 0.079 & 0.078 & 0.078 & 0.079 & 0.318 & 0.858 \\
\hline $90-81$ & $2: 2$ & 0.877 & 0.878 & 0.381 & 0.153 & 0.033 & 0.033 & 0.115 & 0.286 & 3.014 \\
\hline
\end{tabular}

${ }^{\mathrm{z}}$ Each row of this table reports the model solution that most nearly approaches the highest value of the index type listed in this column.

'The probability of at least one chiasma in the long (a) or short (b) arm of the average chromosome.

${ }^{x}$ Proportions of total chromosome association due to each combination of genomes: $S_{1}$ genomes 1 and $2 ; S_{2}$ for 1 and $3 ; S_{3}$ for 1 and 4 , $S_{4}$ for 2 and 3 , $S_{5}$ for 2 and 4 ; and $\mathrm{S}_{6}$ for 3 and 4 .

${ }^{w}$ SSD: minimum sum of squared differences between the observed and expected configuration frequencies.

(90-67, 90-68, 90-69, 90-70, 90-72, 90-74 90-76, 90-77, 90-80, 90-81) and their parents exhibited numerous abnormalities, including chromosome stickiness, fragmentation, asynchronous condensation, cytomixis, and secondary association of all types of configurations (Fig. 1). The frequency of meiotic irregularity varied among genotypes, with meiotically regular cells being least frequent in hybrids $90-77$ and $90-81$. The spectrum of observed meiotic abnormalities is similar to that reported in $R$. rugosa $\times$ R. spinosissima and $R$. rugosa $\times$ R. canina hybrids (Klasterska and Natarajan, 1975). This suggests that $R$. rugosa has diverged from other sections of subgenus Rosa in one or more genes that regulate meiosis, particularly those that control timing.

The number of chromosomes involved in multivalent formation ranged from $4.1(15 \%)$ to $20.7(74 \%)$ in the plants of the full-sib progeny from 'Basye's Blueberry' x 86-7 (Table 1). Meiotically regular cells were most frequent in hybrids 90-68, 90-69, 90-70, and 90-74. Because configuration frequencies varied so much among the 'Basye's Blueberry' $x$ 86-7 hybrids, the optimized values of the model variables varied greatly (Table 2 ). The solutions with the greatest sum of squared differences (SSD) between expected and observed configuration frequencies per cell, i.e., those with the worst fit, probably should be disregarded. For example, the hybrid with the most multivalents (90-72) exceeded the theoretical maximum number of multivalents (4.67) expected for two independent chromosome arms and $\mathrm{x}=7$, and therefore it optimized to a 4:0 pattern with poor fit. Where model fit was closer, as for 90-68 and 90-69, the optimized genomic similarity pattern was $2: 2$, with $80 \%$ to $90 \%$ of the pairing between most similar genomes $\left(s_{1}+s_{6}\right.$; see Table 2$)$. This amount of preferential pairing was consistent with the partial fertility of these hybrids and would preclude strictly disomic inheritance.

None of the model solutions fit well: SSD was $\approx 0.14$ for the closest fits. The cause could be observational errors, as discussed above, and/or significant deviation from the model assumptions of fully independent chromosome arms, equal interference in bivalent and multivalent configurations, and uniformity among all homologous groups in pattern of pairing affinity. Complex hybrids like 'Basye's Blueberry' undoubtedly have experienced homeologous recombination and consequently are effectively translocation-heterozygous with respect to their ancestral genomes. Segregation from these homeologous "translocations" could account for much of the variation in multivalent frequency among the progeny of 'Basye's Blueberry' $x$ 86-7, and for the chronic excess of observed over expected quadrivalents.

Pollen stainability in the raw tetraploid 86-7 (73\%) was reduced considerably relative to its diploid parents (> 90\%). On average, the hybrids of tetraploid 86-7 with 'Basye's Blueberry' were still less fertile, between $60 \%$ and $70 \%$, but more fertile than 'Basye's Blueberry' itself at $52 \%$. There was no correlation of pollen stainability to multivalent frequency or the mean arm-binding frequency $c$ in the 'Basye's Blueberry' $x$ 86-7 hybrids. Therefore, it can be inferred that stainability was also affected by specific genetic interactions, homozygosity at specific loci, or environmental conditions. Lata and Gupta (1975) proposed that meiotic abnormality could enhance fertility of certain hybrids by eliminating chromosomes that bear alleles that are incompatible with the rest of the genotype, but invoking such an argument here seems unnecessary. Almost certainly the genetic regulation of meiosis and pollen development is sufficiently com- plex to cause the observed variability of fertility in these hybrids.

'Basye's Blueberry', 74-193, 86-7, and the hybrids differed considerably in morphological traits (data not shown). In particular, there was a 13:3 segregation of stems with and without prickles among the 'Basye's Blueberry' (no prickles) $x$ 86-7 [( $R$. rugosa (prickles) $\times R$. wichuraiana (no prickles)] hybrid population (16 plants). Prickleless stem is thought to be a recessive trait (Berninger, 1992). Thus its expression in the hybrid population would require segregation of gametes homozygous for a piece of $R$. wichuraiana chromosome that confers no prickles on the stem. Such segregation demands some degree of tetrasomic inheritance in 86-7, which, as a tetraploid, is assumed to be a duplex diallelic for prickles.

The newly created tetraploid, 86-7 (derived from doubling the chromosome number of a diploid interspecific rose hybrid), was sufficiently fertile to use in breeding. Although it was derived from an interspecific hybrid and consequently has an amphidiploid or allotetraploid origin, its cytogenetic behavior was intermediate between an allotetraploid and an autotetraploid, because of chromosome homology between the originating species. Such chromosome homology among species within distinct sections within a subgenera in woody perennial plant groups is not unusual (Grant, 1981). The other tetraploids in this study also showed multivalent formation that involved from $15 \%$ to $74 \%$ of the chromosomes. Although the frequency of multivalent or univalent formation was not related to pollen stainability, this does indicate the possibility of tetrasomic inheritance and homeologous chromosome exchange within tetraploid rose genotypes. In addition, there was the opportunity to select for greater fertility in the hybrid population, which would accelerate 


\section{Breeding, Cultivars, Rootstocks, \& Germplasm Resources}

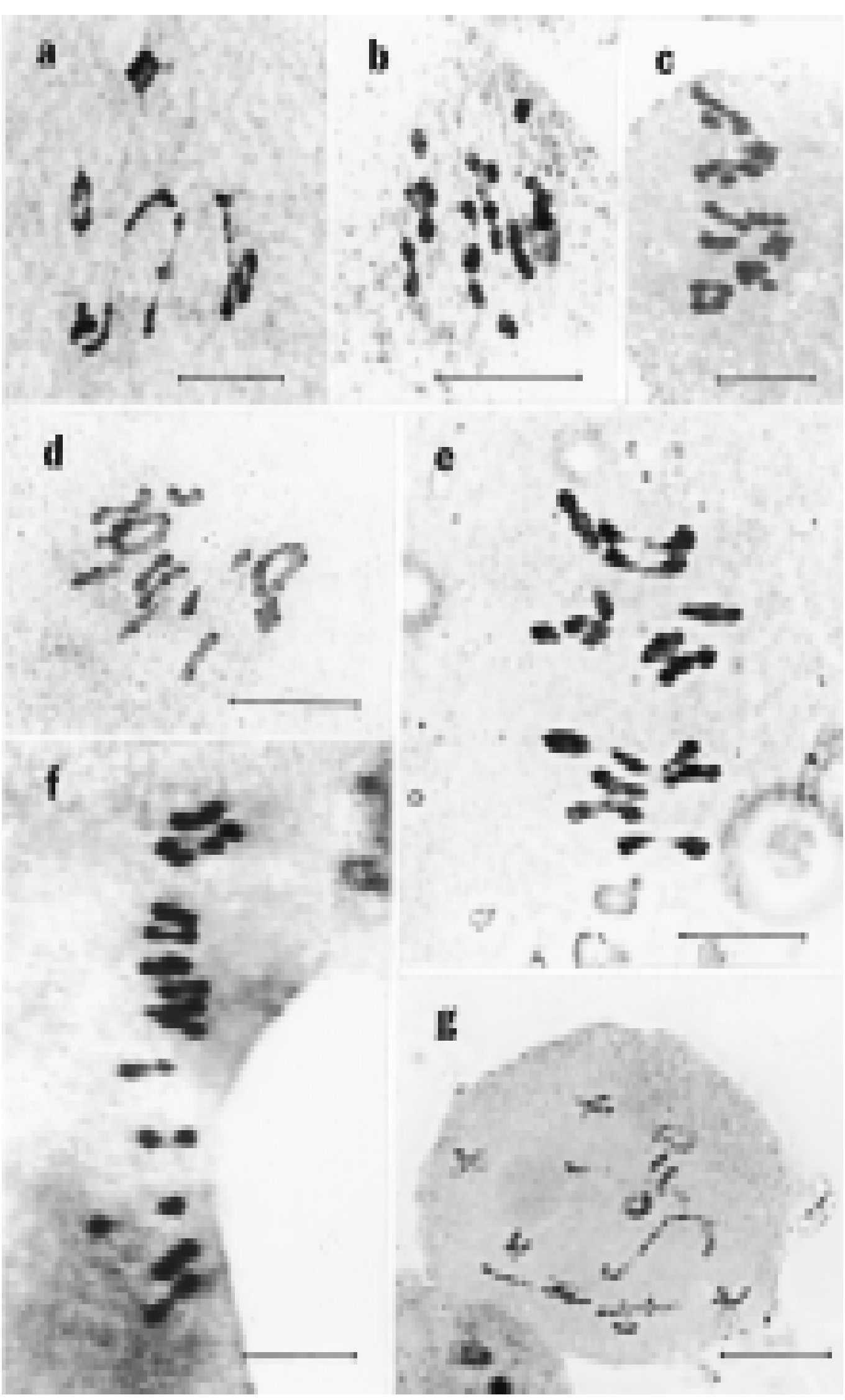

Fig. 1. Meiotic chromosome association at metaphase I (a-f) or diakinesis (g) in the pollen mother cells of rose anther tissue. Bar represents $5 \mu \mathrm{m}$. (a) $86-7$ ( $2 \mathrm{x}$ $=14)$ : three rod bivalents and four ring bivalents; $(\mathbf{b}) 86-7(2 \mathrm{x}=28)$ : three univalents, three ring bivalents, one trivalent, two chain quadrivalents, and two ring quadrivalents; (c) 74-193: two univalents, four rod bivalents, three ring bivalents, and three ring quadrivalents; (d) 82-1134: four rod bivalents, six ring bivalents, and two ring quadrivalents; (e) 82-1134: two univalents, five rod bivalents, and eight ring bivalents; (f) 90-68: one rod bivalent, nine ring bivalents, and two ring quadrivalents; (g) 90-69: five univalents, four rod bivalents, two ring bivalents, one trivalent, and two chain quadrivalents. 
the rate of progress of transferring resistance genes from wild rose species to the cultivated rose gene pool.

\section{Literature Cited}

Berninger, E. 1992. Le rosier de serre pair fleurs à couper, p. 490-504. In: A. Gallais and H. Bannerot (eds.). Amélioration des espéces végétales cultivées. Paris.

Byrne, D.H., W. Black, Y. Ma, and H.B. Pemberton. 1996. The use of amphidiploidy in the development of black spot resistant rose germplasm. Acta Hort. 424:269-272.

Crane, C.F. 1995. Numerical meiotic models for the inference of genomic affinity in polyploids, $p$. 61-79. In Prem P. Jauhar (ed.). Methods of genome analysis in plants: Their merits and pitfalls. CRC Press, Boca Raton, Fla.

Crane, C.F. and D.A. Sleper. 1989. A model of meiotic chromosome association in tetraploids. Genome 32:691-707.

Erlanson, W.E. 1933. Chromosome pairing, structural hybridity, and fragments in Rosa. Bot. Gaz. 94:551-565.
Grant, V. 1981. Plant speciation. Columbia Press, New York.

Hurst, H.H. 1929. Differential polyploidy in the genus Rosa L. Zeitschrift für Induktiv Abstammungs-und Vererbungslehre 2:866-906.

Klasterska, I. 1971. New phenomena during meiosis in the genus Rosa. Hereditas 67:55-64.

Klasterska, I. 1978. Structure of eukaryotic chromosomes: The differences between mammalian (mouse), grasshopper (Stethophyma) and plant (Rosa) chromosomes as revealed at the diffuse stage of meiosis. Hereditas 88:243-253.

Klasterska, I. and A.T. Natarajan. 1974a. Cytological studies of the genus Rosa with special reference to the section Caninae. Hereditas 76:97108.

Klasterska, I. and A.T. Natarajan. 1974b. The role of the diffuse stage in the cytological problems of meiosis in Rosa. Hereditas 76:109-116.

Klasterska, I., and A.T. Natarajan. 1975. Stickiness in Rosa induced by hybridisation. Caryologia 28:80-88.

Krüssmann G, 1981. The complete book of roses. Timber Press, Portland, Ore.

Lata, P. 1982a. Cytological studies in the genus
Rosa II. Meiotic analysis of ten species. Cytologia 47:631-637.

Lata, P. 1982b Cytological studies in the genus Rosa III. Meiotic analysis of ten cultivars. Cytologia 47:639-647.

Lata, P. and M.N. Gupta. 1975. Effects of ionizing radiation on roses: Meiotic studies on control and gamma ray induced mutants of rose cultivar Montezuma. Cytologia 40:213-219.

Ma, Y., D.H. Byrne, and J. Chen. 1997. Colchicineinduced amphidiploids of rose interspecific hybrids. HortScience 32:292-295.

McConnell, J. and H. Kamemoto. 1993. Morphology and meiotic behavior of three Dendrobium amphidiploids and their diploid counterparts. HortScience 28:935-937.

Rehder, A. 1940. Manual of cultivated trees and shrubs. Macmillan, New York.

Shepherd R.E. 1954. History of the rose. Macmillan, New York.

Sybenga, J. 1975. Meiotic configurations. SpringerVerlag, Berlin.

Teoh, S.B. and E.C. Ong. 1983. Differential meiotic behaviour in hybrid clones of Aranda 'Christine' (Orchidaceae). Euphytica 32:799-806. 